\title{
Extreme storms cause rapid, context-dependent shifts in nearshore subtropical bacterial communities
}

Ángela Ares $1^{*}$, Margaret Mars Brisbin $1^{*}$, Kirk N. Sato1,2, Juan P. Martín1, Yoshiteru linuma3,

5 Satoshi Mitarai 1

${ }^{*}$ contributed equally

1 Marine Biophysics Unit, Okinawa Institute of Science and Technology (OIST, Okinawa, Japan)

2 Friday Harbor Laboratories, University of Washington (U.S.A.)

3 Instrumental Analysis Section, Okinawa Institute of Science and Technology (OIST, Okinawa, Japan)

15

Climate change scenarios predict tropical cyclones will increase in both frequency and intensity, which will escalate the amount of terrestrial run-off and mechanical disruption affecting coastal ecosystems. Bacteria are key contributors to ecosystem functioning, but relatively little is known about how they respond to extreme storm events, particularly in nearshore subtropical regions.

20 In this study, we combine field observations and mesocosm experiments to assess bacterial community dynamics and changes in physicochemical properties during early- and late-season tropical cyclones affecting Okinawa, Japan. Storms caused large and fast influxes of freshwater and terrestrial sediment-locally known as red soil pollution-and caused moderate increases of macronutrients-especially $\mathrm{SiO}_{2}$ and $\mathrm{PO}_{43}$. We detected shifts in relative abundances of

25 marine bacteria and the introduction of terrestrially-derived bacteria, including putative coral and human pathogens, during storm events. Soil input alone did not substantially affect marine bacterial communities in mesocosms, indicating that other components of run-off or other storm effects likely exert a larger influence on bacterial communities. The storm effects were shortlived and bacterial communities quickly recovered following both storm events. The early- and late-season storms caused different physicochemical and bacterial community changes, demonstrating the context-dependency of extreme storm responses in a subtropical coastal ecosystem. 


\section{Keywords}

35 Tropical cyclones, typhoons, hurricanes, extreme events, bacterioplankton, coastal, nearshore, community dynamics, soil pollution, run-off

\section{Introduction}

40 Extreme storm events, such as tropical cyclones (i.e. tropical storms, hurricanes, and typhoons), can have dramatic consequences on coastal ecosystems, due in part to the effects of terrestrially-derived pollution (Hennessy et al., 1997; De Jesus Crespo et al., 2019). In addition to influencing salinity and turbidity, flood plumes often include elevated concentrations of bacteria (Solo-Gabriele et al., 2000), nutrients (i.e. C, N, P) (Chen et al., 2012, 2018; Gao et al.,

45 2014; Paerl et al., 2018) and other chemicals, such as herbicides or heavy metals (Lewis et al., 2012; Mistri et al., 2019), which can act synergistically to negatively affect coastal ecosystems (Wooldridge, 2009; Brodie et al., 2012; Lewis et al., 2012). Especially in tropical and subtropical coastal ecosystems, which experience severe seasonal storms, large volumes of terrestrial runoff can enter coastal waters and can degrade coral reefs directly, through sedimentation or

50 disease (Riegl and Branch, 1995; Philipp and Fabricius, 2003; Voss and Richardson, 2006; Haapkylä et al., 2011; Wilson et al., 2012). Such run-off events can also harm reefs indirectly, through eutrophication, hypoxia (Fabricius, 2005; Altieri et al., 2017) and decreased water quality. As global climate change is expected to enhance the frequency and intensity of extreme storm events (Groisman et al., 2005), it is increasingly important to better understand how such

55 storms impact coastal ecosystem functioning.

Tropical cyclones are most active in the western North Pacific, where there is an average of 27 named storms per year (Wang et al., 2010; Herbeck et al., 2011) and where landfalling 
typhoons are specifically expected to become more common and more destructive (Mei and

60 Xie, 2016). Okinawa Island, the largest island of the Ryukyu archipelago at the edge of the western North Pacific, is an ideal natural laboratory for studying storm effects on coastal ecosystems. Okinawa's coral reefs have experienced significant declines in recent decades, due in part to increased storm induced run-off and sedimentation (Omori, 2011; Hongo and Yamano, 2013; Harii et al., 2014), which is exacerbated by agricultural practices and large coastal development projects (Omija, 2004; Masucci and Reimer, 2019). The fine-particle, laterite soils with high iron concentrations found in Okinawa and typical to the region are easily suspended and turn coastal waters a deep, cloudy red color during the frequent tropical cyclones (Supplemental Figure 1) (Omija, 2004). These events are locally referred to as Red Soil Pollution (Omori, 2011).

While the biological consequences of storm-induced run-off have been investigated for corals and fish species in Okinawa (Hongo and Yamano, 2013; Inoue et al., 2014; Yamazaki et al., 2015; O'Connor et al., 2016; Yamano and Watanabe, 2016), less is known about how tropical cyclones and the associated run-off affects coastal microbial communities and especially

75 bacteria (Blanco et al., 2008). Microbial communities contribute to marine ecosystems through primary production and by recycling dissolved organic carbon and nutrients through the microbial loop (Azam et al., 1983), but can also draw down dissolved oxygen (Anderson and Taylor, 2001) and can cause opportunistic infections in marine organisms (Shinn et al., 2000; Sutherland et al., 2011; Sheridan et al., 2014; Peters, 2015). Therefore, changes in microbial 80 community compositions in response to storms could precipitate large-scale ecosystem effects. Microbial responses can occur extremely quickly; Gammaproteobacteria, Flavobacteria and many Alphaproteopbacteria can increase in abundance within hours when exposed to high nutrient concentrations, whereas the entire microbial community-including archaea, protists, and viruses - can turn over on the scale of less than one day to about a week (Fuhrman et al., 
85 2015). Rapid microbial response times to changing environmental conditions make microbes valuable early-warning bioindicators (Glasl et al., 2017; Pearman et al., 2018), but also hinders their study. Sampling at the scale of microbial response times during tropical cyclones is often dangerous and is further complicated by the poor predictability of storm tracks and event intensities (Zhou et al., 2012).

90

In this study, we characterize nearshore bacterial community dynamics in response to tropical cyclones affecting Okinawa Island and isolate the effects of sediment input through controlled mesocosm experiments. The study included tropical storm Gaemi at the start of the 2018 Okinawa typhoon season (June 16) and successive category 5 super typhoons, Trami and

95 Kong-Rey, on September 30 and October 5, towards the end of the 2018 season. We evaluated physicochemical properties and bacterial community compositions in seawater samples collected before, during/between, and after storms in June and October and in samples taken from mesocosms with and without red soil amendment. Mesocosm experiments were undertaken in order to isolate the effects of red soil input from other storm effects, such as wind,

100 waves, and fresh-water influx. The specific aims for this study were to: i) assess how bacterial community composition and physicochemical parameters respond in time to tropical cyclones and sediment input, ii) evaluate the speed of the responses and recovery, and iii) identify potential ecosystem consequences due to extreme storms and sediment input.

\section{Results}

\section{Physicochemical responses to extreme storm events and red soil input}

Two major storm events affecting Okinawa Island were monitored for this study. The first event 110 included tropical storm Gaemi, which made landfall on June 16 and was the first tropical cyclone 
of the 2018 typhoon season. Gaemi brought $133.72 \mathrm{~mm}$ day-1 of precipitation and maximum wind speeds of $12.1 \mathrm{~m} \mathrm{~s}-1$ to Okinawa (Figure 1). Substantial precipitation and wind were also recorded during the two days leading up to Gaemi's landfall (69.77 and $83.99 \mathrm{~mm}$ day-1 precipitation and 10.2 and $12.1 \mathrm{~m} \mathrm{~s}-1$ wind intensity on June 14 and 15, respectively), but no

115 additional rain was recorded until July (Figure 1). The second event included two category-5 super-typhoons, Trami and Kong-Rey, which impacted Okinawa in rapid succession towards the end of the 2018 season (Sept. 29 and Oct.5). Trami and Kong-Rey caused accumulated rainfall of 239.24 and $87.89 \mathrm{~mm}$ day-1and maximum wind speeds of 26.9 and $12.7 \mathrm{~m} \mathrm{~s}-1$, respectively. The June and October events represented the two largest rainfalls during the 2018 typhoon 120 season, and typhoon Trami recorded the most extreme sustained and gusting wind speeds in 2018 (Figure 1). The extreme winds accompanying Trami and Kong-Rey also caused very large waves; Trami and Kong-Rey both brought waves with heights greater than nine meters (Japan Meteorological Agency, https://www.data.jma.go.jp/gmd/kaiyou/shindan/index_wave.html). 


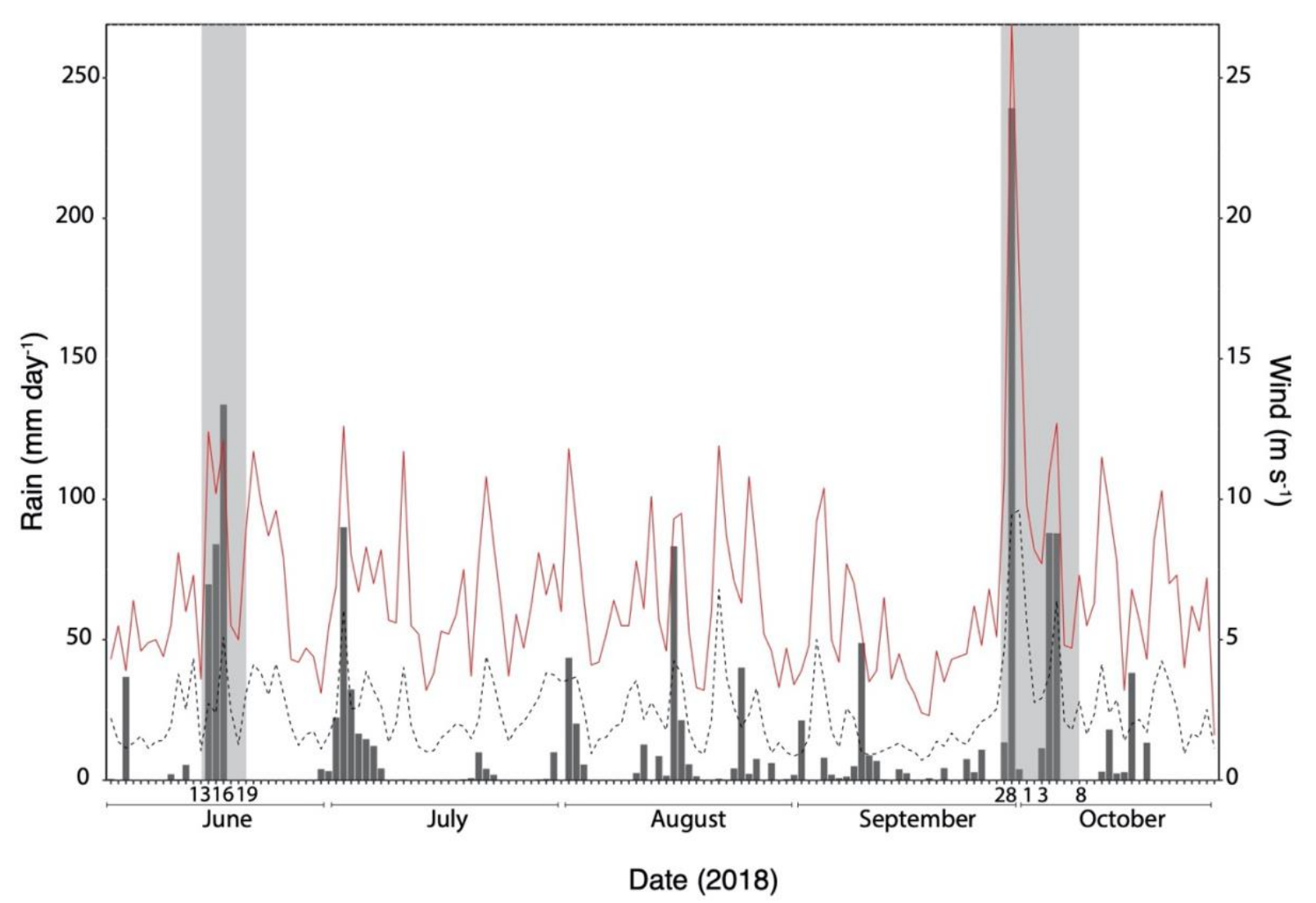

Figure 1. Precipitation (in $\mathrm{mm}$ day-1) and wind speed (m s-1) during the 2018 typhoon season in Okinawa, Japan. Data were collected with the meteorological station located at OIST Marine Science Station $\left(26.510046{ }^{\circ} \mathrm{N}, 127.871721^{\circ} \mathrm{E}\right)$ from June through October, corresponding to the duration of the typhoon season in Okinawa. Bars represent the daily amount of rain (in $\mathrm{mm}$ ); dashed black and red lines indicate daily mean and maximum wind speeds (in $\mathrm{m} \mathrm{s}$-1); shaded areas represent the two red soil pollution events monitored in this study: Tropical Storm Gaemi on June 16 and the super-typhoons Trami and KongRey on September 29 and October 5. The dates when water samples were collected for chemical and DNA analyses are noted on the $x$-axis.

Temperature $\left({ }^{\circ} \mathrm{C}\right)$, DO (mg L-1), salinity (\%o) and turbidity (NTU) were measured in situ at the four nearshore field sites at the same time that water samples were collected. There was a 135 significant decrease in salinity $(\sim 15 \%)$ and concurrent increase of turbidity $(\sim 10$-fold $)$ during the storm on June 16 compared to before the storm on June 13 and afterwards on June 19 (Figure 2). Up to a $5 \%$ decrease in salinity and 3 NTU increase in turbidity was measured between the two storms in October (Oct 1 and 3). These changes were smaller in magnitude than were recorded for the June storm and were not statistically significant, despite the storms in October 

accompanying the October storms was also much more intense (Figure 1), which presumably mixed the water column more thoroughly and prevented freshwater lenses from forming, thus contributing to diminished changes in salinity and turbidity being observed in October compared to June.

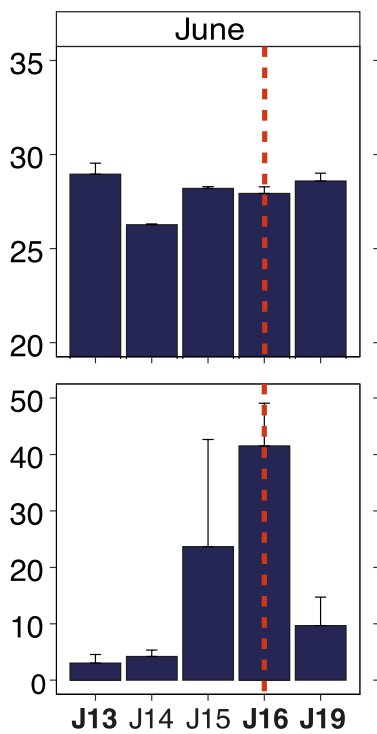

145

150

Figure 2. Temporal variation of temperature $\left({ }^{\circ} \mathrm{C}\right)$, turbidity (NTU), salinity $(\%)$ and dissolved oxygen (DO; mg L-1) before, during, and after storm events in June and October, 2018. Bars represent mean concentrations of dissolved temperature $\left({ }^{\circ} \mathrm{C}\right)$, turbidity (NTU), salinity (\%) and DO (mg L-1) for four sampling sites along the central west coast of Okinawa, Japan. Sampling dates when samples were also processed for metabarcode analyses are indicated in bold on the $\mathrm{x}$-axis. Red dashed vertical lines represent the timing of storms and corresponding red soil pollution events. All measurements were taken with a CTD profiler.

Concentrations of dissolved nutrients, including $\mathrm{NO}_{2-}, \mathrm{NO}_{3-}, \mathrm{NH}_{4+}, \mathrm{PO}_{43-}, \mathrm{SiO}_{2}$, and dFe, were measured in seawater samples collected in June and October (Figure 3) and throughout the second mesocosm experiment (Supplemental Figure 7). Overall, dissolved nutrient concentrations were higher in June than October, with the exception of $\mathrm{dFe}$ and $\mathrm{SiO}_{2}$, which both had similar values in the two sampling months (Figure 3). A nonparametric Kruskall-Wallis test was applied to detect significant storm-induced differences in field nutrient concentrations 160 (Supplemental Table 3). Results showed significant increases $(p<0.05)$ in $\mathrm{NO}_{2}$ - concentrations 
during and following storm events in June and October, whereas $\mathrm{SiO}_{2}$ and $\mathrm{PO}_{43}$ - were only significantly elevated during and after the storm in June (Figure 3).

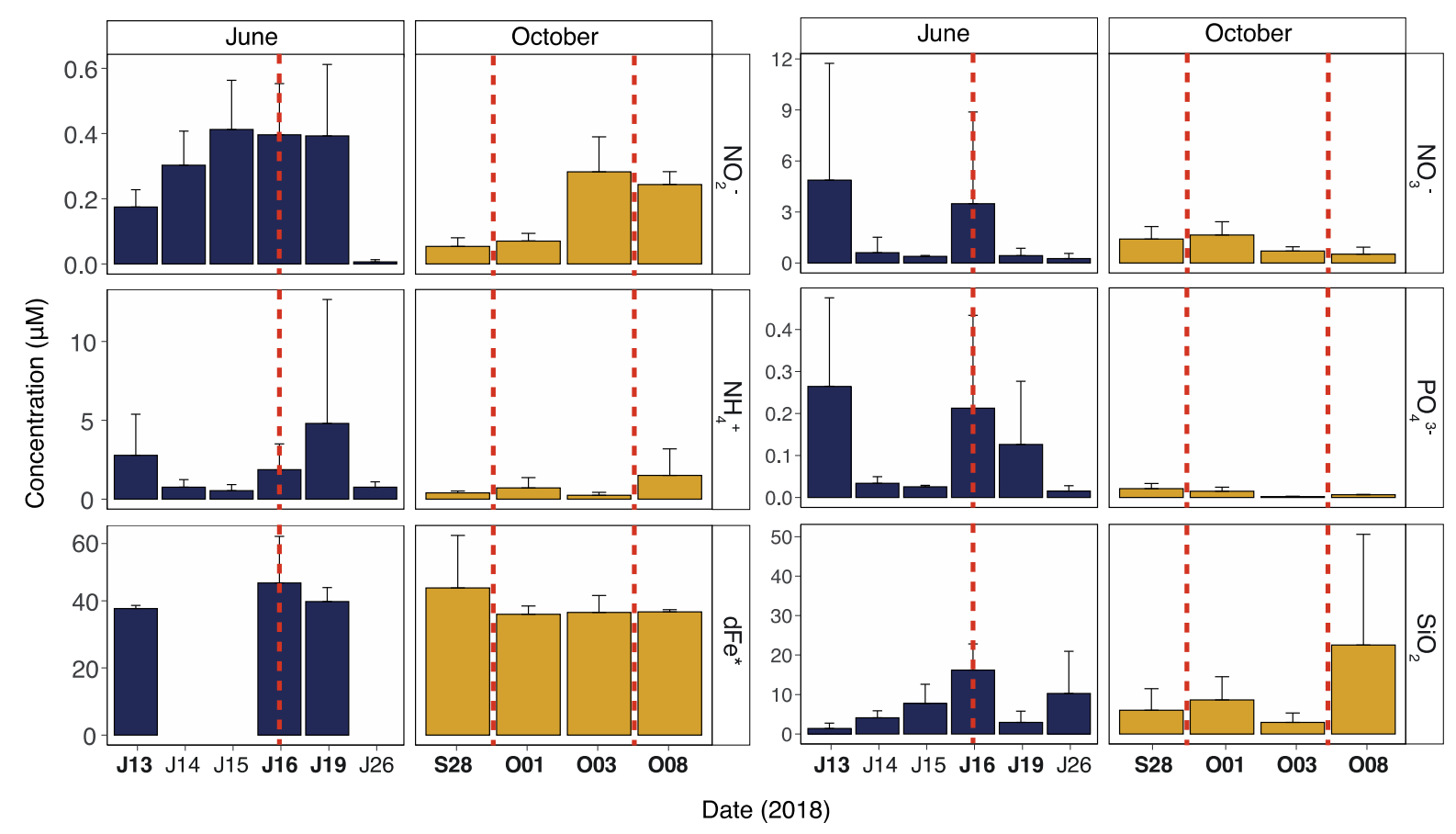

Figure 3. Temporal variation of micro- and macro-nutrient concentrations before, during, and after storm events in June and October, 2018. Bars represent mean concentrations of dissolved $\mathrm{NO}_{2-}, \mathrm{NO}_{3-}$, $\mathrm{NH}_{4+}, \mathrm{PO}_{43}, \mathrm{SiO}_{2}$, and $\mathrm{dFe}$ ( ${ }^{*} \mathrm{dFe}$ concentration is in $\mathrm{nM}$ ) for four sampling sites along the central west coast of Okinawa, Japan. Error bars represent one standard deviation of the mean from four replicates. Red dashed vertical lines represent the timing of major storms and associated red soil pollution events. Sampling dates when samples were also processed for metabarcode analyses are indicated in bold on the $x$-axis. Nutrient concentrations were determined on a QuAAtro39 Continuous Segmented Flow Analyzer and dFe concentration was determined by ICP-MS after $\mathrm{Mg}(\mathrm{OH})_{2}$ co-precipitation using the isotope dilution method (Wu and Boyle, 1998).

Red soil addition in the October mesocosm experiment caused a significant increase in

$175 \mathrm{SiO}_{2}$ concentration (Supplemental Figure 7, Supplemental Table 4). Additionally, red soil addition caused $\mathrm{PO}_{43}$ - concentrations to increase above the detection limit 4 hours following soil addition, whereas $\mathrm{PO}_{43}$ - stayed below the detection limit in control mesocosms after the initial measurement (Supplemental Figure 7). Two-way ANOVA results (Supplemental Table 4) indicate that time had a greater effect on nutrient concentration $\left(p<0.05\right.$ for $\mathrm{NO}_{2}$, $\mathrm{SiO}_{2}$ and 
only significant in the case of $\mathrm{SiO}_{2}(p<0.05)$, for which higher concentrations were found in soiltreated mesocosms.

\section{Bacterial community responses to storm events and red soil input}

Metabarcoding with the bacterial $16 \mathrm{~S}$ ribosomal RNA gene was performed to evaluate shifts in bacterial community composition associated with extreme storms in the field and with sediment input in mesocosms. There was a clear shift in the relative abundances of bacterial phyla in field samples collected during the June storm compared to before or afterwards.

Several phyla that were also present in soil samples became more abundant in the water

190 samples collected during the storm-including Acidobacteria, Actinobacteria, Chloroflexi, Firmicutes, Rokubacteria and Verrumicrobia_but phyla absent in soil samples also became more abundant during the storm, most notably Epsilonbacteraeota (Figure 4). Principal coordinate analysis ( $\mathrm{PCoA})$ of Aitchison distances between bacterial community compositions in water samples also illustrated a clear shift in community composition during the June storm event; samples collected during the storm clustered separately along the primary axis from the samples collected both before and after the event (Figure 5). The shift in community composition during the storm was accompanied by an increase in ASV richness (Figure 6); estimated ASV richness was significantly higher in samples collected during the June storm compared to samples collected before and afterwards. 

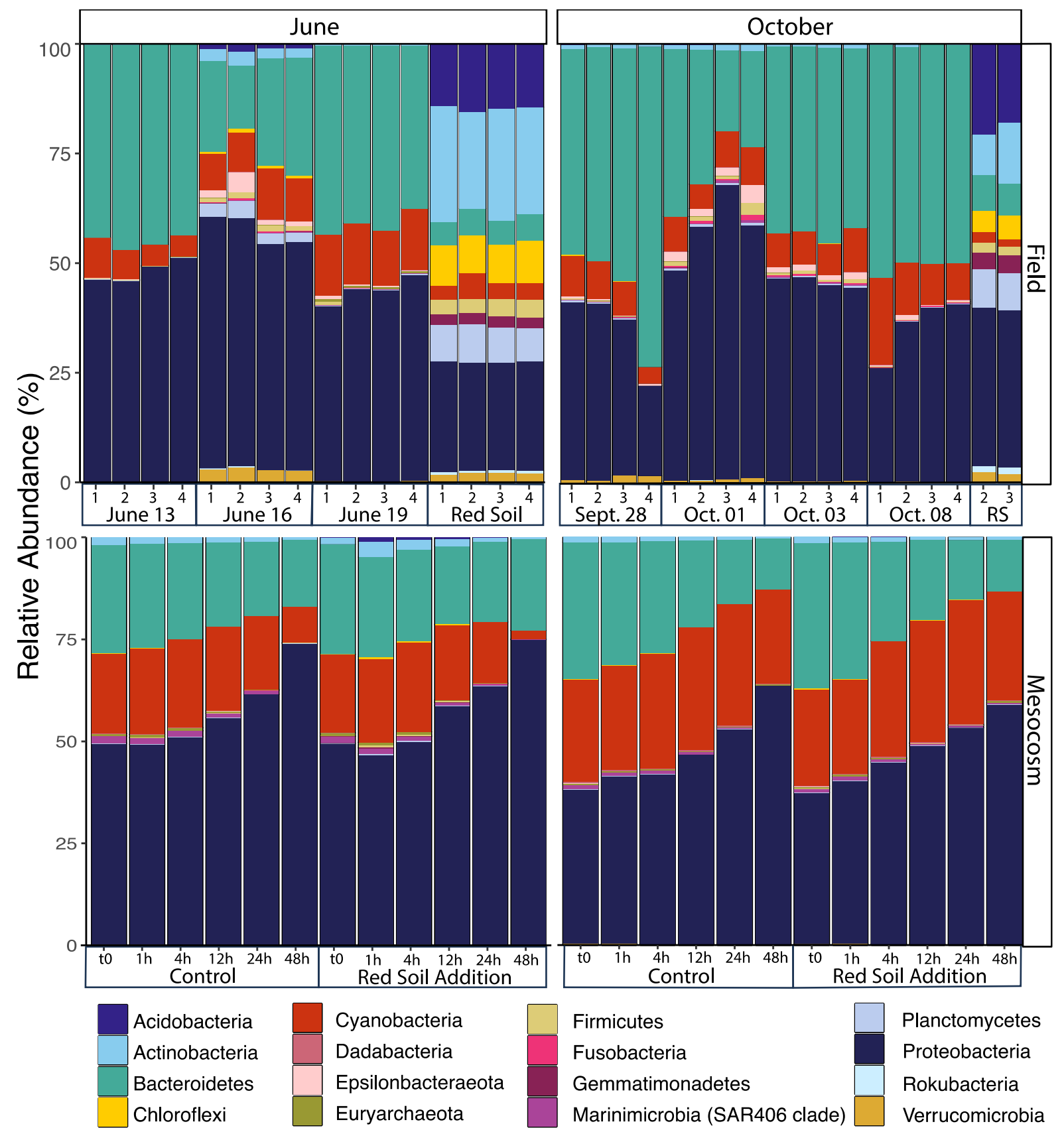

$$
\begin{aligned}
& \text { Cyanobacteria } \\
& \text { Dadabacteria } \\
& \text { Epsilonbacteraeota } \\
& \text { Euryarchaeota }
\end{aligned}
$$

\begin{tabular}{|c|c|}
\hline Firmicutes & Planctomycetes \\
\hline Fusobacteria & Proteobacteria \\
\hline Gemmatimonadetes & Rokubacteria \\
\hline Marinimicrobia (SAR406 clade) & Verrucomicrobia \\
\hline
\end{tabular}

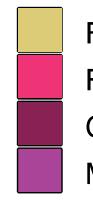

Figure 4. Relative abundance of prokaryotic phyla in field and mesocosm samples collected in June and October, 2018. Each stacked bar represents the relative contribution of major bacterial phyla to the total community at one sampling location, in one red soil sample, or at one time point in mesocosms 215 (mesocosm bars represent aggregate data from 4-5 replicates depending on month and treatment). Sampling stations 1-4 were sampled before, during, and after red soil pollution events triggered by major storms in June and October 2018. In June, 6/13 was before the event, 6/16 was during the event, and the 6/19 was after the event. In October, 9/28 was before the event, 10/01 and 10/03 were between events, and 10/08 was after events. Red soil samples are labeled with replicate number and were collected close 220 to the dates storms occured in June and October. Red soil (200 mg L-1) was added to treatment mesocosms immediately following the to sampling. 
Soil addition to June mesocosms also influenced bacterial community composition and richness, although to a lesser extent than the storm-influenced nearshore communities.

Bacterial phyla dominant in soil samples were detectable in mesocosm samples taken one hour 225 after soil addition, but their abundance diminished in samples taken 24 hours later (Figure 5).

Likewise, ASV richness increased in samples taken from mesocosms following soil addition and decreased over time (Supplemental Figure 9). Overall, mesocosm incubation time had a larger effect on bacterial community composition than soil addition (Figure 4, Supplemental Figure 10), despite mesocosm conditions (temperature, salinity, DO) remaining similar to ambient

230 conditions throughout the experiment (Supplemental Figures 5-6).

A. June

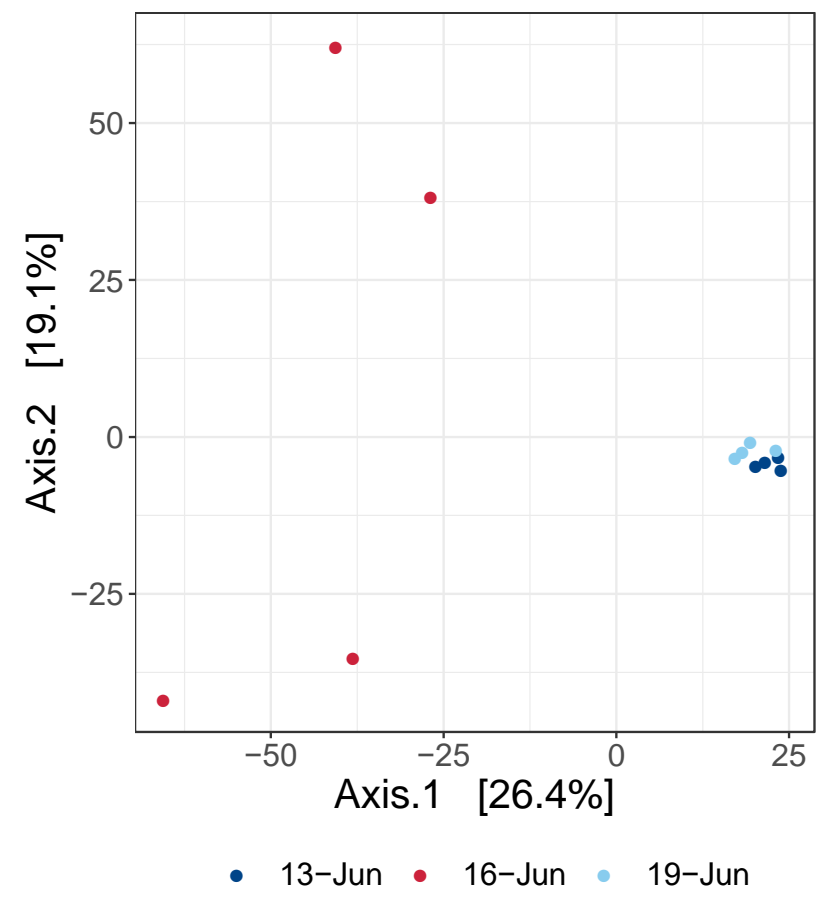

B. October

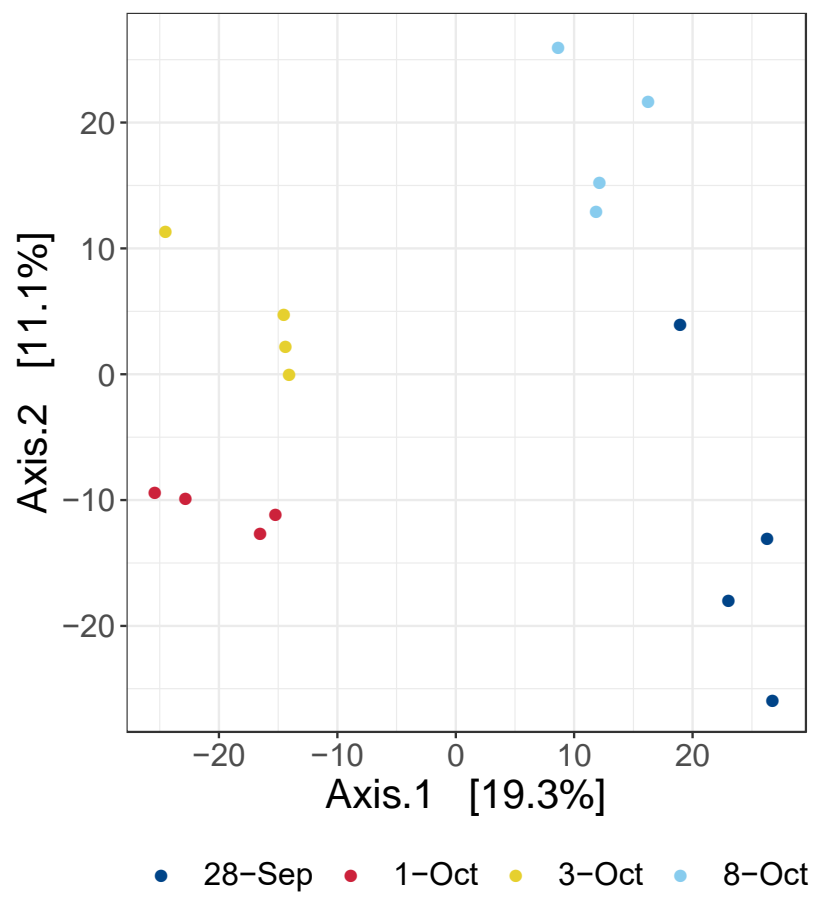

Figure 5. Principal coordinates analysis (PCoA) of Aitchison distances between prokaryotic community composition before, during, and after storm events in June (A) and October (B), 2018. (A) June 13 was before the June storm, 6/16 was during, and 6/19 was after. For the October event (B), 235 9/28 was before the storms, 10/01 and 10/03 were between, and 10/08 was after. Samples collected during/between storm events cluster separately from samples collected before and after for both the June and October events. 


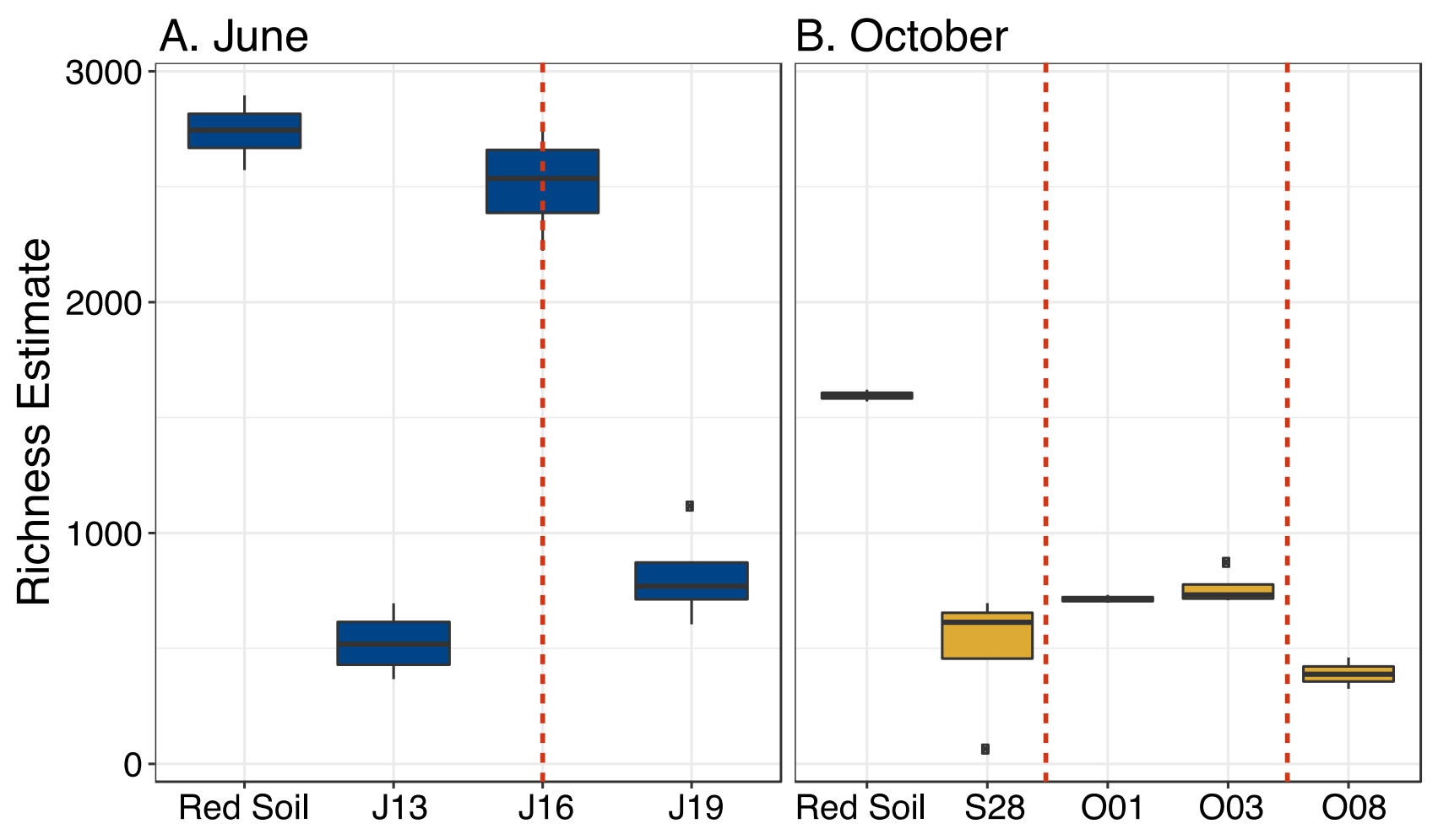

Figure 6. Richness estimates for bacterial communities in red soil samples and surface water samples collected before, during, and after storm events in June (A) and October (B), 2018. Red 245 dashed vertical lines represent the timing of major storms and associated red soil pollution events. In June (A), the red soil samples had significantly higher richness than the water samples collected before and after the event, but not samples collected during the event. In October (B), red soil samples had significantly higher richness than all water samples and richness was not significantly different in water samples collected before, during, or after the storms. Differences in richness were considered significant when $p<$ $250 \quad 0.05$.

In October, the community composition also shifted between the two storms relative to before and after the overall storm event. Additionally, some phyla present in soil samples, particularly Firmicutes, increased in relative abundance between the storms, but similar to in

255 June, phyla absent from soil samples also increased in relative abundance (e.g.

Epsilonbacteraeota and Fusobacteria). However, unlike in June, Actinobacteria, Planctomycetes, and Verrucomicrobia were already detectable in water samples collected before the storm event occurred (Figure 4). PCoA further demonstrated a shift in community composition in samples collected between the October storms compared to before and 
260 afterwards; samples collected between the two storms clustered separately on the primary axis from samples collected before and after the event (Figure 5). Interestingly, the estimated ASV richness was lower (by about half) for all samples collected in October compared to in June, including in soil samples, and estimated richness did not increase in the samples collected between storms (Figure 6). Community compositions in field samples from the different months

265 segregated into two clusters along the primary axis in PCoA and the differences were statistically significant in PERMANOVA $\left(p<0.01, F=5.37, R_{2}=0.17\right)$, demonstrating that nearshore bacterial communities were distinct in June and October (Supplemental Figure 8). Furthermore, soil addition to October mesocosms did not cause observable increases in relative abundances of phyla found in soil samples as it had in June (Figure 4, Supplemental Figure 9). In order to identify individual taxa that became more abundant during storms and, thus, contributed to the broader patterns observed in the data, we performed pairwise testing for differentially abundant ASVs between sampling dates in each month. The greatest number of significantly differentially abundant ASVs were found in the pairwise test between June 13 (before the storm) and June 16 (during the storm), with the vast majority being more abundant 275 during the storm (Figure 7A). In contrast, very few ASVs were significantly differentially abundant in samples collected before and after the June storm (Figure 7A). While many of the ASVs that were significantly more abundant during the storm on June 16 were also detected in soil samples, the majority were not (Figure 7A, B). ASVs that were significantly more abundant on June 16 compared to June 13 belonged to a total of 67 orders-including Flavobacteriales,

280 Campylobacterales, and Vibrionales, which can be pathogenic to humans and marine organisms (Pruzzo et al., 2005; Silva et al., 2011; Loch and Faisal, 2015; Canty et al., 2020), and Rhizobiales, Sphingomonadales, and Alteromonadales, which were also found in soil samples (Figure 7B). In pairwise tests for October samples, the largest number of differentially abundant ASVs were likewise found between samples collected before (Sept. 28) and during 285 storms (Oct. 1 and 3), but none of the differentially abundant ASVs were also found in soil 
bioRxiv preprint doi: https://doi org/10.1101/801886: this version posted May 22, 2020. The copyright holder for this preprint (which was not certified by peer review) is the author/funder, who has granted bioRxiv a license to display the preprint in perpetuity. It is made available under aCC-BY 4.0 International license.

samples (Figure 7C, D). ASVs that were significantly differentially abundant between samples taken before and during the October storms belonged to 21 different orders, with most, but not all, also represented in the June results (Figure 7D).

A.

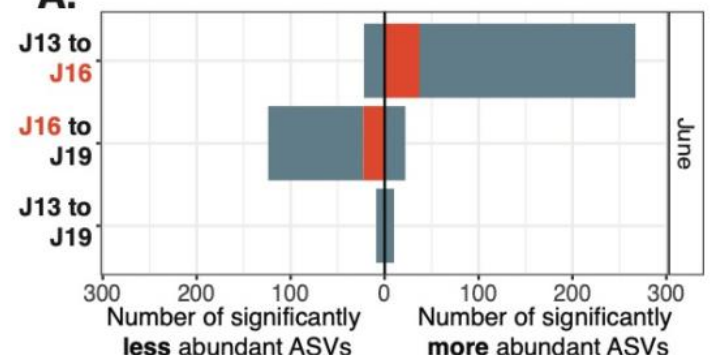

B.

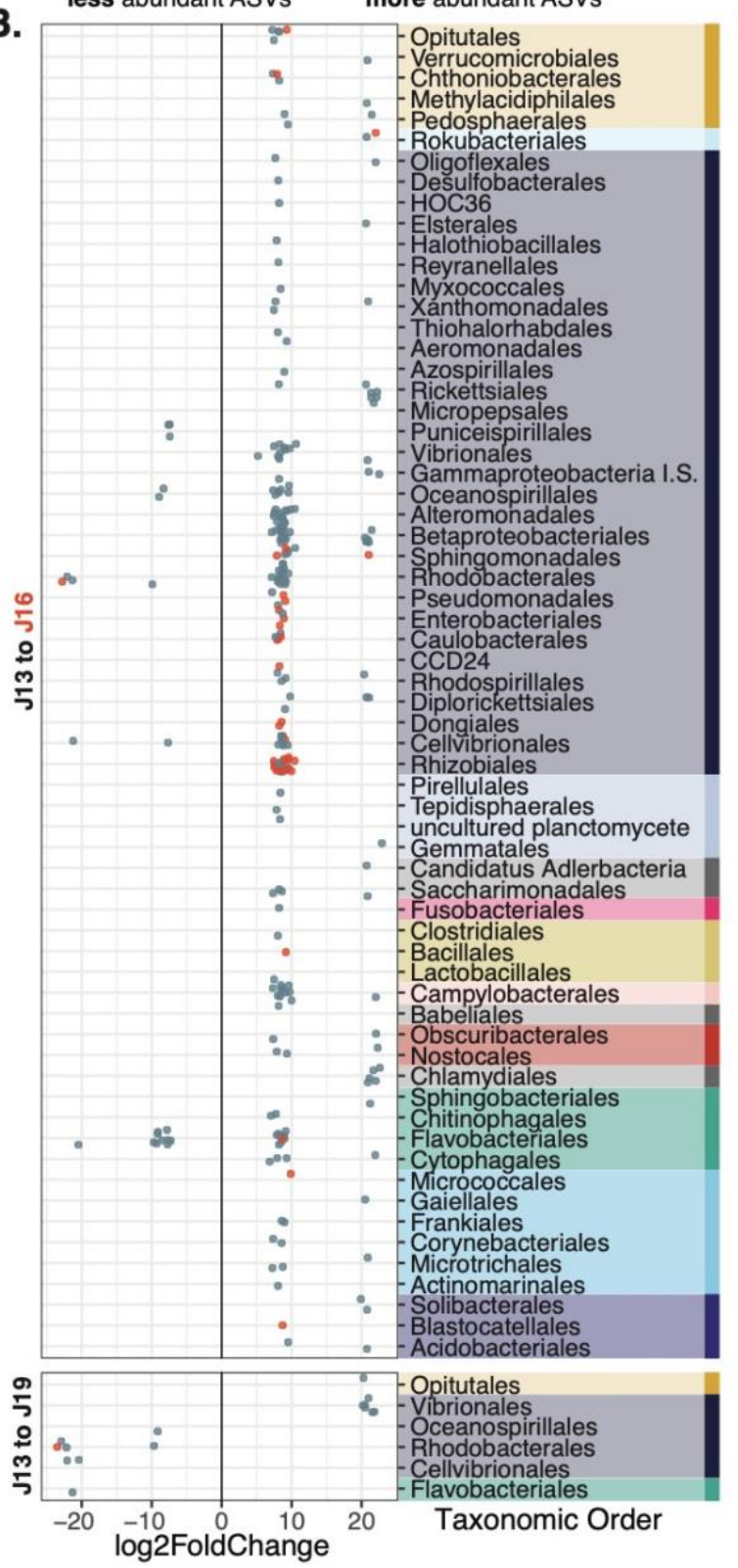

C.

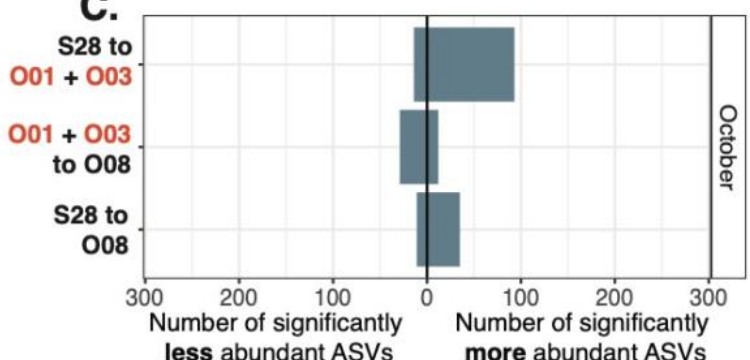

D.
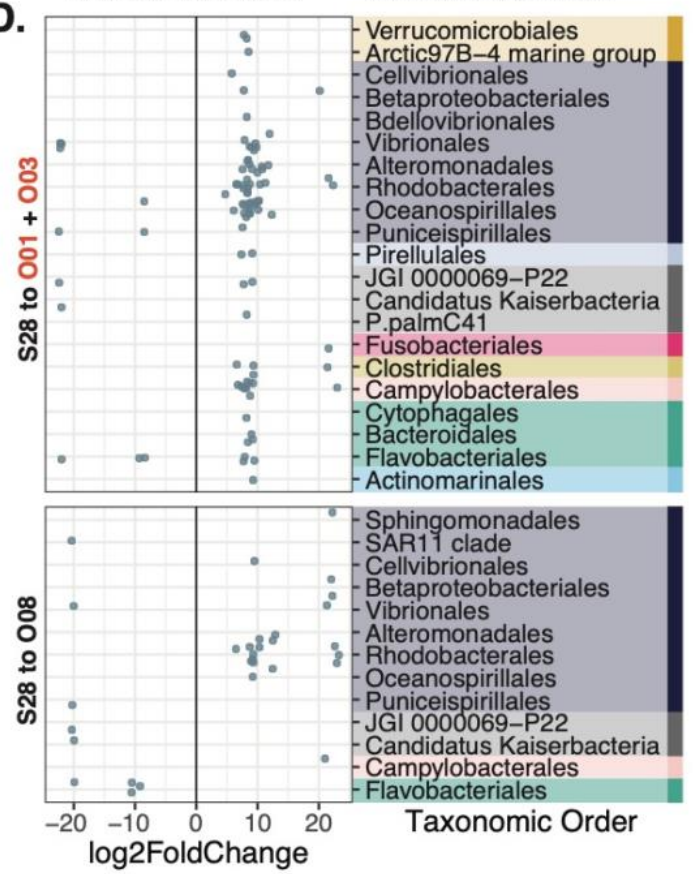

Not found in soil samples

Found in soil samples

Phylum:

\begin{tabular}{|c|c|}
\hline Verrucomicrobia & Epsilonbacteraeota \\
\hline Rokubacteria & Cyanobacteria \\
\hline Proteobacteria & Bacteroidetes \\
\hline Planctomycetes & Actinobacteria \\
\hline Fusobacteria & Acidobacteria \\
\hline Firmicutes & Other \\
\hline
\end{tabular}


290 Figure 7. Number of Amplicon Sequence Variants (ASVs) significantly differentially abundant in pairwise comparisons between sampling dates in June (A) and October (C) and log2 Fold Change of individual ASVs in pairwise comparisons from before to during storms and from before to after storms in June (B) and October (D), 2018. ASVs were considered significantly differentially abundant when the FDR adjusted $p$-value was less than 0.05. ASVs that were also present in soil samples are colored

295 red in panels A and B; no differentially abundant ASVs in pairwise tests for October samples were found to be present in October soil samples. Positive log2FoldChange values ( $x$-axis, B, D) indicate higher abundance of ASVs during/between storms compared to before (J13 to J16, S28 to O01 + O03) or after storms compared to before (J13 to J19, S28 to O08). Differentially abundant ASVs are grouped by taxonomic order and orders are color coded by phylum so that colors correspond to Figure 4 .

\section{Discussion}

As the severity and frequency of extreme storm events increases with global climate change, it is increasingly important to understand how these events impact ecological functioning in

305 marine ecosystems (Wetz and Paerl, 2008; Du et al., 2019). However, characterizing the effects of extreme storm events, such as typhoons, on coastal ecosystems is a complicated task, due both to forecast unpredictability, which makes sampling before and after events challenging, and the dangerous conditions that accompany storms (Chen et al., 2018). This study reports on the near-shore microbial community dynamics and relevant environmental parameters in two

310 short time-series encompassing major storms during the 2018 typhoon season in Okinawa, Japan. In addition, concurrent, controlled mesocosm experiments were performed to supplement field observations and isolate impacts of terrestrial sediment input that regularly accompanies large storms in Okinawa. Predictably, storms caused influxes of both freshwater and sediment into the coastal marine environment (Figure 2, Supplemental Figure 1), which

315 carried some soil-derived bacteria and some bacteria presumably derived from other terrestrial sources (Figure 4, Figure 7). Remarkably though, the effects of the storms were extremely short-lived, and bacterial community compositions quickly recovered. While field samples were collected three days following storm events, mesocosm experiments showed that the bacterial community began recovering only four hours after soil addition and was fully recovered after just 
32024 hours. Despite the rapidity of community shifts, terrestrially derived bacteria and marine bacteria that increased in abundance during and after storms can still be detrimental to coastal ecosystems and dangerous to human health. For instance, bacteria that became more abundant following storms can cause diseases in corals (e.g. Vibrio spp., Pseudoalteromonas sp., Rhodobacteraceae bacteria) and humans (e.g. Campylobacter, Fusobacteria,

325 Enterobacter), thus necessitating a better understanding of the sources and sinks for these bacteria in the coastal environment (Pruzzo et al., 2005; Vizcaino et al., 2010; Silva et al., 2011; Zimmer et al., 2014; Figure 7).

\section{Extreme storms cause rapid changes in environmental conditions and bacterial}

\section{0 community composition}

During the storm event in June, we measured a drastic drop in salinity and increased turbidity in nearshore surface waters (Figure 2), which is similar to previous reports following major storm events (De Carlo et al., 2007; Zhou et al., 2012; Chen et al., 2018). The influx of freshwater and sediment was accompanied by moderate increases in $\mathrm{NO}_{2-}, \mathrm{NO}_{3-}, \mathrm{NH}_{4+}, \mathrm{PO}_{43-}, \mathrm{SiO}_{2}$ and dFe concentrations (Figure 3), which is consistent with terrestrial run-off from agricultural areas with high iron-content soil, as is found in Okinawa (Arakaki et al., 2005). However, increased nutrient loading dissipated before samples were collected again 3 days after the June storm (Figure 3). Likewise, there was an increase in bacterial diversity (Figure 6) representing the introduction of

340 bacterial phyla that were found in our soil samples and are common components of soil microbiomes, including Acidobacteria, Actinobacteria, Chloroflexi, Firmicutes, Planctomycetes, Rokubacteria and Verrucomicrobia (Figure 4; Witt et al., 2012; Balmonte et al., 2016; Lin et al., 2019) and additional phyla presumably deriving from other marine or terrestrial sources, such as Epsilonbacteraeota. Three days following the storm, on June 19, the alpha diversity returned to 345 pre-storm levels (Figure 6A) and the community composition was almost identical to before the 
storm (Figure 5A). Moreover, only 19 ASVs were significantly differentially abundant between June 13 and June 19 compared to 267 ASVs between June 13 and June 16 (Figure 7A), demonstrating the incredible speed at which the microbial community recovered. The ephemeral presence of bacteria also found in the soil samples was similarly apparent in the

350 June mesocosm experiment. One hour after soil was added to treatment mesocosms, phyla dominant in soil samples (e.g. Acidobacteria, Chloroflexi, Firmicutes, and Planctomycetes) were detected, but their relative abundance decreased in samples taken four and twelve hours later, and they were absent in samples taken 24 hours later. The transience of storm-effects on nearshore bacterial communities was further demonstrated in results from the October storm

355 event. The bacterial community recovered just three days after super-typhoon Kong-Rey passed, the second super-typhoon to affect Okinawa in less than a week (Figure 5B).

\section{Extreme storms cause context-dependent changes in environmental conditions and bacterial community composition}

While storm effects were extremely transient in both cases (Figure 5), the June and October storm events affected coastal physicochemistry and bacterial community composition differently (Figure 2, 3 and 4). Events in both June and October increased coastal NO2- loading, but only the June event was accompanied by increased $\mathrm{PO}_{43}$ - and $\mathrm{SiO}_{2}$ concentrations, and the 365 June storm caused more pronounced shifts in bacterial community composition, highlighted by a larger increase in ASV richness and a higher number of differentially abundant ASVs.

Although these differences may reflect disparate sampling schemes, it is likely that differences in wind and rain intensity and the contexts in which the two events occurred also had a strong effect. Key differences between the June and October events were that much more rain, wind 370 and wave action accompanied the October storm event than the June storm and that the June 
storm made landfall at the beginning of the typhoon season, whereas the October storms affected Okinawa towards the end of the typhoon season.

Typhoon Trami, on Sept. 29, caused twice as much precipitation as tropical storm Gaemi, on June 16 (Figure 1), which could have diluted nutrient loading in storm run-off and

375 caused the smaller changes in nutrient concentrations recorded in October compared to in June (Figure 3). When flushing rate is high, less $\mathrm{PO}_{43}$ - is desorbed from sediments and there is a dilution effect for both dissolved phosphorus and nitrogen in run-off (Blanco et al., 2010). Additionally, Gaemi was the first major storm of the 2018 typhoon season (June-October) following a relatively prolonged dry period, which could increase nutrient loading in storm run-

380 off, especially since agricultural fertilizers are applied throughout the preceding spring and summer growing season. By October, several tropical storms and typhoons had already affected Okinawa (Figure 1); the 2018 Pacific typhoon season had higher than average storm frequency and included 29 tropical storms, 13 typhoons, and 7 super typhoons, although not all made direct landfall with Okinawa (Japan Meteorological Agency,

385 https://www.jma.go.jp/jma/indexe.html). These intervening events could have stripped topsoil and depleted soil nutrients and microbiomes, so that October storm run-off carried less nutrients, organic material, and terrestrial bacteria into coastal water than storm run-off in June. Moreover, antecedent soil moisture affects dissolved nutrient loading in run-off, with less nutrients desorbing from clay-based soils, like Okinawa red soil, when wet (Perrone and 390 Madramootoo, 1998).

The controlled mesocosm experiments offer additional insight for interpreting differences in field observations between June and October. Despite collecting soil from the same place in June and October, the soil microbiome was much less diverse in October (Figure 5) and soil addition to October mesocosms did not introduce soil bacteria or increase bacterial diversity as

395 it had in June mesocosms (Figure 4, Supplemental Figure 9). These results suggest that soils in Okinawa could have lower bacterial loading towards the end of the typhoon season. 
Furthermore, soil addition in October mesocosms did not cause nitrogen ( $\mathrm{NO}_{2}$ - or $\mathrm{NO}_{3}$ ) or dFe to increase over baseline measurements, but did cause increases in $\mathrm{SiO}_{2}$ and $\mathrm{PO}_{43}$

(Supplemental Figure 7). However, the increase in $\mathrm{SiO}_{2}$ and $\mathrm{PO}_{43}$ - were gradual, demonstrating

400 that time is required to release these compounds from red soil (De Carlo et al., 2007; Blanco et al., 2010; Chen et al., 2018). Soils in Okinawa could, therefore, have lower nitrogen content at the end of the typhoon season and more intense rains may deliver less nutrients due to rapid flushing.

\section{Influence of extreme storms on bacterial taxa in nearshore waters}

The influence of June and October storms on coastal microbial communities varied in magnitude, but in both instances the community shift was rapid and transient and included several common bacterial groups that became more abundant; 15 out of the 21 bacterial orders

410 encompassing ASVs that were significantly more abundant during the October event were shared with the June event (Figure 7). These shared bacterial orders included primarily heterotrophic bacteria, several of which contain potentially pathogenic groups (e.g. Vibrionales, Fusobacteriales, and Campylobacterales) (Pruzzo et al. 2005; Silva et al. 2011; Canty et al. 2020). Originally, we expected cyanobacteria to respond to increased inorganic nutrients

415 delivered to the coastal ecosystem with storm run-off. Specifically, we expected nitrogen fixers-such as Trichodesmium, which occasionally blooms near Okinawa (Grossmann et al., 2015) - to benefit from increased dFe and $\mathrm{PO}_{43}$ - in run-off (Sañudo-Wilhelmy et al., 2001; Wu et al., 2003). Instead, only a few cyanobacteria ASVs became more abundant during the June storm, but not the October storm (Figure 7). Namely, cyanobacteria belonging to the family

420 Oscillatoriaceae, which form filamentous benthic mats (Siegesmund et al., 2008; Engene et al., 2018), and Obscuribacterales, which are uncultured and have unknown morphology, but may not be photosynthetic (Soo et al., 2014), became more abundant in June. There are several 
possible explanations for the minimal changes in cyanobacteria relative abundance: i)

cyanobacteria were not limited by compounds present in run-off, ii) nutrients in run-off were not

425 biologically available, or iii) terrestrial run-off was transported offshore or diluted too quickly to affect nearshore communities. Nutrient concentrations that were elevated during the June storm ( $\mathrm{NO}_{2-}, \mathrm{NO}_{3-}, \mathrm{PO}_{43-}$ and $\mathrm{dFe}$ ) decreased after the storm passed, but not immediately and not as quickly as the microbial communities recovered (Figure 3). Since nutrients were not immediately drawn down, the nearshore microbial community may not have been nutrient limited in our study

430 area. The limited bacterial response to soil addition in mesocosms, despite increased $\mathrm{PO}_{43}$-and dFe in October, further suggests that nutrient availability was not driving community composition. The heterotrophic bacteria that became more abundant during and after storms could have derived from the soil or other components of the run-off, been resuspended from the benthos due to wind and waves, or increased in abundance in response to organic matter in the 435 run-off.

\section{Potential ecosystem consequences due to terrestrial run-off from extreme storms}

Despite being short-lived, the changes we observed in bacterial community composition and 440 environmental parameters during storms can nevertheless be detrimental to both the coastal ecosystem and human health. While most terrestrially-derived bacteria are benign to marine ecosystems, many are potentially pathogenic to corals and other marine organisms (Sutherland et al., 2004; Haapkylä et al., 2011; Pollock et al., 2014; Sheridan et al., 2014). Terrestrial run-off has been implicated in coral diseases, such as White Pox Disease and Red Band Disease, in

445 many tropical and subtropical locations, including Madagascar (Haapkylä et al., 2011; Pollock et al., 2014; Sheridan et al., 2014), the Caribbean (Frias-Lopez et al., 2002; Patterson et al., 2002), and Australia's Great Barrier Reef (Pollock et al., 2014). Furthermore, storm events can cause water-column mixing and sediment resuspension, leading to pathogenic marine bacteria 
that usually inhabit the seafloor to become more abundant in the water column (Hassard et al.,

450 2016). Indeed, in our study we found several strains of Vibrio spp., Pseudoalteromonas sp., and Rhodobacteraceae bacteria specifically associated with coral disease (Sussman et al., 2008; Sheridan et al., 2014) to be significantly enriched in samples we collected during or following storm events, which could be caused by either terrestrial influence or marine resuspension (Supplemental Table 5). Considering the additional stress caused by turbidity and sedimentation

455 during storm events, alongside potentially decreased $\mathrm{pH}$ and $\mathrm{DO}$ due to enhanced heterotrophic bacterial respiration (Weber et al., 2012; Altieri et al., 2017), corals and other organisms may be especially susceptible to pathogen infection during and after extreme storms.

Heavy rains and floods have long been implicated in transporting human pathogens (e.g. fecal

460 coliform bacteria) to the marine environment (Pandey et al., 2014; De Jesus Crespo et al., 2019). Indeed, we found bacterial taxa that are potentially dangerous to humans-including Campylobacterales, Fusobacteriales, Bacillales, Clostridiales and Enterobacteriales (Bennett and Eley, 1993; Sharma et al., 2003; Davin-Regli et al., 2019)—significantly enriched during and following storms. Many of these bacteria were not detected in soil samples, suggesting 465 additional sources of bacterial contamination in storm run-off. For instance, some of the Bacillales and Enterobacterales ASVs enriched in storm-influenced water samples were not present in soil samples and none of the enriched Clostridiales, Campylobacterales and Fusobacteriales ASVs were also found in soil samples (Figure 7). Likewise, these taxa were not found in mesocosms following soil addition in June or October, demonstrating the larger effect 470 of storms and run-off on the coastal ecosystem than simply transporting sediment into the water. Human pathogens may derive from live-stock, storm drains, or overwhelmed waste treatment plants during storms (Weiskel et al., 1996; Jamieson et al., 2004). Interestingly, these taxa were already present in water samples collected on September 28-although they were more abundant on October 1 and 3-further indicating a cumulative effect of the typhoon 
475 season on the coastal ecosystem and emphasizing the context-dependency of storm effects. Ultimately, swimmers and other recreational users need to be aware that pathogenic bacteria are likely present in Okinawa coastal waters following large rain events.

\section{Conclusions \& Future Directions}

Despite challenges associated with sampling marine ecosystems during tropical storms and typhoons, this study describes the timing and nature of storm effects on coastal bacterial communities in Okinawa, Japan. We found that storm effects were transient, but highly contextdependent. The transient nature of storm effects should not be viewed as diminishing their

485 potential impact on reef or human health. Differentially abundant bacteria during storms may cause disease in marine organisms and humans. We coupled controlled mesocosm studies with field observations in an effort to disentangle the effects of extreme wind and waves and enhanced currents from the effects of soil input during storms. While the mesocosm results were useful, future studies would benefit from more realistic run-off simulation than the soil

490 additions we employed. Furthermore, it remains that we did not perform bacterial cell counts or otherwise measure bacterial biomass or metabolic activity, thus leaving the possibility that runoff increased microbial biomass or differentially affected microbial physiology. Future studies may capture such responses by measuring bacterial respiration rates or by performing metatranscriptomics.

It is important to note that environmental effects of extreme storms will vary in terms of intensity, spatial extent and duration in different ecosystems and need to be evaluated locally (Paerl et al., 2006; Zhang et al., 2009; Herbeck et al., 2011). Storm effects were transient in the open, tidallyflushed Okinawa coast, but more prolonged storm effects have been observed in other coastal 500 systems, particularly semi-enclosed areas, such as bays and estuaries, where terrestrial 
sediment loads can have residence times from weeks to years (Paerl et al., 2001; Zhang et al., 2009; Herbeck et al., 2011). Therefore, we suggest that the short-term study of typhoon events follow an adaptive sampling strategy (Wetz and Paerl, 2008), which involves the definition of well-established baselines for various physicochemical and biological parameters. Regional

505 monitoring programs, including a comprehensive understanding of background conditions, are essential for a better interpretation of ecological consequences of extreme storm events.

\section{Experimental Procedures}

\section{Study setting}

Seawater was collected for metabarcoding and physicochemical analysis from four nearshore sampling points approximately 250-500 m apart, along the central west coast of Okinawa Island-a semi-urban region with mixed land-use, including agriculture and coastal development projects (Supplemental Figure 2). The sampling points were each at least $1.2 \mathrm{~km}$ from the

515 nearest concentrated fresh-water input (e.g. streams or rivers). At the start of the 2018 typhoon season, samples were collected before (June 13), during (June 16), and after (June 19) tropical storm Gaemi, which struck Okinawa on June 16, 2018 and caused a red soil pollution event (Figure 1, Supplemental Figure 3A). Towards the end of the typhoon season, samples were collected before (Sept 28), during (Oct 1 and Oct 3) and after (Oct 8) a red soil pollution event

520 caused by typhoon Trami, which made landfall with Okinawa on September 30, and was prolonged by Typhoon Kong-Rey, which approached Okinawa on October 5th (Figure 1, Supplemental Figure 3B-C).

\section{Seawater sampling for DNA and physicochemical analysis}


525 Surface seawater was collected for DNA metabarcoding by submerging clean $500 \mathrm{~mL}$ Nalgene bottles just below the sea surface. Seawater for dissolved Fe (dFe) and nutrient analysis was collected in acid-cleaned $50 \mathrm{~mL}$ Falcon tubes. Physicochemical properties-dissolved oxygen (DO), salinity, temperature, and turbidity—were measured with a CTD RINKO profiler (JFE Advantech, Japan) at each site. After being immediately transported to the laboratory, seawater 530 samples for metabarcoding were filtered through $0.2 \mu \mathrm{m}$ pore-size Polytetrafluoroethylene (PTFE) filters (Millipore) under gentle vacuum and filters were stored at $-20{ }^{\circ} \mathrm{C}$ for later DNA extraction. Seawater samples for dFe and nutrient analysis were filtered through $0.45 \mu \mathrm{m}$ poresize acid-washed Teflon digiFILTERS (SPC Science, Canada) and filtered water samples were stored at $-20{ }^{\circ} \mathrm{C}$ for later chemical analysis.

\section{Mesocosm experimental design}

Seawater was collected for concurrent mesocosm experiments on June $11\left(26.512^{\circ} \mathrm{N}\right.$, 127.872 $\mathrm{E})$ and October $10\left(26.479^{\circ} \mathrm{N}, 127.829^{\circ} \mathrm{E}\right)$. Nearshore coastal seawater was pumped from just below the sea surface and filtered through $1 \mathrm{~mm}$ and $300 \mu \mathrm{m}$ nylon mesh sizes to

540 remove debris and larger organisms. Acid-cleaned $22 \mathrm{~L}$ clear-plastic carboys were rinsed twice with seawater before filling to $20 \mathrm{~L}$ with filtered seawater. Bottles were covered with parafilm and kept shaded during transport to the Okinawa Institute of Science and Technology (OIST) Marine Science Station, where they were submerged in a basin with continuous flow-through seawater to keep conditions within the bottles similar to natural conditions. Mesocosm bottles were

545 topped with silicone sponge stoppers to allow gas exchange, but limit evaporation and prevent dust, water or other contaminants from entering the bottles during the experiment

(Supplemental Figure 4). In addition, small pumps were included in each mesocosm to maintain water circulation (2 L min-1). HOBO temperature and light loggers (Onset) were fastened to the pumps and at the same depth in the basin surrounding mesocosms to ensure that mesocosms 550 conditions remained similar to ambient conditions (Supplemental Figure 5). In addition, salinity 
and DO were measured each time water was sampled from the mesocosms throughout the experiment (Supplemental Figure 6). Mesocosms experiments included 9-10 mesocosms: 4-5 control replicates (four in June and five in October) and 5 treatments replicates with red soil added to an ecologically relevant concentration of $200 \mathrm{mg} \mathrm{L-1}$ (O'Connor et al., 2016).

555 Mesocosms were sampled (100 mL for metabarcoding, $50 \mathrm{~mL}$ for dFe and nutrient concentration) with $50 \mathrm{~mL}$ sterile pipettes before the experiment started (t0), and 1, 4, 12, 24, and $48 \mathrm{~h}$ following red soil addition to treatment bottles. Water samples were processed as described in the previous section.

\section{Red soil collection for mesocosm experiments and DNA analysis}

Soil samples were collected from an open agricultural field with exposed soil $\left(26.507^{\circ} \mathrm{N}\right.$, 127.868 ${ }^{\circ} \mathrm{E}$ ), on June 10 and October 9 for addition to red soil treated mesocosms and to evaluate soil microbiomes. Soil samples were sieved through $330 \mu \mathrm{m}$ mesh and maintained at 4 ${ }^{\circ} \mathrm{C}$ for $24 \mathrm{~h}$ until use in the mesocosm experiment. To determine soil moisture content, $10 \mathrm{~g}$ 565 subsamples $(n=10)$ were weighed and dried at $100^{\circ} \mathrm{C}$ by following the standard method AS 1289.2.1.1-2005 (Standards Association of Australia). Soil moisture content was used to calculate how much wet soil should be added to mesocosms in order to reach the final concentration of $200 \mathrm{~g}$ soil (dry weight) per $\mathrm{L}$ seawater. In both June $(\mathrm{n}=4)$ and October $(\mathrm{n}=2)$, additional $50 \mathrm{~g}$ aliquots of soil were kept at $-20^{\circ} \mathrm{C}$ for subsequent metabarcoding analysis.

\section{Chemical analysis: dFe and major nutrients}

Dissolved Fe (dFe) concentration was determined following the methodology of Wu and Boyle (1998). This method uses a $\mathrm{Mg}(\mathrm{OH})_{2}$ co-precipitation to pre-concentrate Fe from seawater followed by an isotope dilution method. Seawater dFe was quantified using an internal standard

575 element $\left({ }_{57} \mathrm{Fe}\right)$ with inductively coupled plasma mass spectrometry (Element 2, Thermo Scientific). The mass spectrometer was operated in medium-resolution mode with 4000 
resolution (FWHM). The mass calibration was performed using a multi-element ICP-MS tune-up solution (Thermo Fisher Scientific). In order to ensure the quality of the ICP-MS analysis, control standards and samples (i.e. analytical replicates, certified reference material and analytical

580 blank) were analyzed once every 12 samples. Recovery of Fe from reference certified material QC3163 (Sigma-Aldrich, USA) was satisfactory and ranged from 65 to $80 \%$. The overall error associated with the analytical process was typically lower than 5\% and never higher than $15 \%$. All measurements were above the instrument's detection limit. Analysis was carried out at the OIST Instrumental Analysis Section mass spectrometry laboratory. Special attention was paid to 585 avoid Fe contamination and an exhaustive cleaning process was carried out following the methods of (King and Barbeau, 2011).

Nutrient concentrations-including Nitrate ( $\left.\mathrm{NO}_{3}\right)$, Nitrite $\left(\mathrm{NO}_{2-}\right)$, Ammonium $\left(\mathrm{NH}_{4+}\right)$, Phosphate (PO43-) and Silica $\left(\mathrm{SiO}_{2}\right)$ —were determined on a QuAAtro39 Continuous Segmented Flow

590 Analyzer (SEAL Analytical) following manufacturer guidelines. Final concentrations were calculated through AACE software (SEAL Analytical). Nutrient Analysis was carried out at the Okinawa Prefecture Fisheries and Ocean Technology Center.

\section{Nutrient and dFe statistical analyses}

595 Mesocosm data were found to be normally distributed with a Shapiro-Wilks test and, therefore, a one-way ANOVA was performed to test overall differences between treatments. Post-hoc Tukey HSD analysis was performed to identify which specific groups differed. Field data were not normally distributed, regardless of transformation, so a Kruskal-Wallis test was used to test for significant differences between sampling dates. Analyses were performed within the $R$ 600 statistical environment (R Core Team 2018).

\section{DNA extraction and metabarcode sequencing}


DNA was extracted from frozen PTFE filters following the manufacturer protocol for the DNeasy PowerWater Kit (Qiagen), including the optional heating step. DNA was extracted from soil

605 samples by following manufacturer protocol for the DNeasy PowerSoil Kit (Qiagen).

Metabarcode sequencing libraries were prepared for the V3/V4 region of the bacterial 16S ribosomal RNA gene following Illumina's “16S Metagenomic Sequencing Library Preparation” manual without any modifications. Sequencing libraries were transferred to the OIST Sequencing Center for $2 \times 300-b p$ sequencing on the Illumina MiSeq platform with v3 chemistry.

610 Overall, 18.4 million sequencing reads were generated in this study, with 76,217-219,584 sequencing reads per sample (mean $=137,585)$. Sequencing data are available from the NCBI Sequencing Read Archive under the accession PRJNA564579.

\section{Metabarcode analyses}

615 Sequencing reads were denoised using the Divisive Amplicon Denoising Algorithm (Callahan et al., 2016) with the DADA2 plug-in for QIIME 2 (Bolyen et al., 2019). Following denoising, 11.8 million sequences remained with $11,061-153,646$ sequences per sample (mean $=88,033$ ). A total of 36,007 ASVs were identified in our dataset, with 64-2,886 unique ASVs observed per sample (mean $=642$ ). Taxonomy was assigned to representative ASVs using a Naive Bayes

620 classifier trained on the SILVA 97\% consensus taxonomy (version 132, (Quast et al., 2013) with the QIIME 2 feature-classifier plug-in (Bokulich et al., 2018). The results were imported into the R statistical environment (R Core Team 2018) for further analysis with the Bioconductor phyloseq package (McMurdie and Holmes, 2013). The ASV richness for each sample was estimated using the R package breakaway (Willis and Bunge, 2015) and differences in

625 estimated richness between sample types were tested for with the betta function (Willis et al., 2017). In order to minimize compositional bias inherent in metabarcoding data as much as possible, we used the Aitchison distance between samples (Gloor et al., 2017) for principal 
coordinate analyses (PCoA). Permutational analyses of variance (PERMANOVA) on Aitchison distances were performed with the adonis function (999 permutations) in the R package vegan

630 (Oksanen et al., 2019) to test whether shifts in community composition were statistically significant. Lastly, we used the DESeq2 bioconductor package (Love et al., 2014) to determine which ASVs were significantly differentially abundant (False Discovery Rate adjusted $p$-value < 0.05 ) in water samples collected from field sites before, during, and after storms. We then checked if significantly differentially abundant ASVs were also present in soil samples from

635 respective months to assess whether differentially abundant ASVs were soil-derived. Intermediate data files and the code necessary to replicate analyses are available in a GitHub repository: https://github.com/maggimars/RedSoil.

\section{Acknowledgments}

640 We thank Akinori Murata and Marine Le Gal for help with sample collection, Kazumi Inoha, Koichi Toda, Kosuke Mori and Okinawa Marine Science Support Section, OIST for assistance with experimental design and technical support and Koichi Kinjo from the Okinawa Prefectural Institute of Health and Environment for his advice. We also thank OIST sequencing center for DNA sequence support and Okinawa Prefecture Fisheries and Ocean Technology Center for

645 nutrient analysis assistance. MMB was supported by a Japan Society for the Promotion of Science (JSPS) DC1 graduate student fellowship. This work was supported by the JSPS KAKENHI program [Early-Career Project No. 18K18203] and the OIST Marine Biophysics Unit. Furthermore, we confirm that we have no conflicts of interest to disclose.

\section{Reference list}

Altieri, A.H., Harrison, S.B., Seemann, J., Collin, R., Diaz, R.J., and Knowlton, N. (2017) Tropical dead zones and mass mortalities on coral reefs. Proc Natl Acad Sci U S A 114: 3660-3665. 
655 Anderson, T.H. and Taylor, G.T. (2001) Nutrient pulses, plankton blooms, and seasonal hypoxia in western Long Island Sound. Estuaries 24: 228-243.

Arakaki, T., Fujimura, H., Hamdun, A.M., Okada, K., Kondo, H., Oomori, T., et al. (2005) Simultaneous Measurement of Hydrogen Peroxide and Fe Species (Fe(II) and Fe(tot)) in Okinawa Island Seawater: Impacts of Red Soil Pollution. J Oceanogr 61: 561-568.

660 Azam, F., Fenchel, T., Field, J.G., Gray, J.S., Meyer-Reil, L.A., and Thingstad, F. (1983) The Ecological Role of Water-Column Microbes in the Sea. Marine Ecology Progress Series 10: 257-263.

Balmonte, J.P., Arnosti, C., Underwood, S., McKee, B.A., and Teske, A. (2016) Riverine Bacterial Communities Reveal Environmental Disturbance Signatures within the Betaproteobacteria and Verrucomicrobia. Front Microbiol 7: 1441.

Bennett, K.W. and Eley, A. (1993) Fusobacteria: new taxonomy and related diseases. J Med Microbiol 39: 246-254.

Blanco, A.C., Nadaoka, K., and Yamamoto, T. (2008) Planktonic and benthic microalgal community composition as indicators of terrestrial influence on a fringing reef in Ishigaki

670 Island, Southwest Japan. Mar Environ Res 66: 520-535.

Blanco, A.C., Nadaoka, K., Yamamoto, T., and Kinjo, K. (2010) Dynamic evolution of nutrient discharge under stormflow and baseflow conditions in a coastal agricultural watershed in Ishigaki Island, Okinawa, Japan. Hydrol Process 24: 2601-2616.

Bokulich, N.A., Kaehler, B.D., Rideout, J.R., Dillon, M., Bolyen, E., Knight, R., et al. (2018) Optimizing taxonomic classification of marker-gene amplicon sequences with QIIME 2's q2feature-classifier plugin. Microbiome 6: 90.

Bolyen, E., Rideout, J.R., Dillon, M.R., Bokulich, N.A., Abnet, C.C., Al-Ghalith, G.A., et al. (2019) Reproducible, interactive, scalable and extensible microbiome data science using QIIME 2. Nat Biotechno/ 37: 852-857.

680 Brodie, J.E., Kroon, F.J., Schaffelke, B., Wolanski, E.C., Lewis, S.E., Devlin, M.J., et al. (2012) Terrestrial pollutant runoff to the Great Barrier Reef: An update of issues, priorities and management responses. Mar Pollut Bull 65: 81-100.

Callahan, B.J., McMurdie, P.J., Rosen, M.J., Han, A.W., Johnson, A.J.A., and Holmes, S.P. (2016) DADA2: High-resolution sample inference from Illumina amplicon data. Nat Methods

685 13: $581-583$.

Canty, R., Blackwood, D., Noble, R., and Froelich, B. (2020) A comparison between farmed oysters using floating cages and oysters grown on-bottom reveals more potentially human pathogenic Vibrio in the on-bottom oysters. Environ Microbiol.

Chen, N., Krom, M.D., Wu, Y., Yu, D., and Hong, H. (2018) Storm induced estuarine turbidity maxima and controls on nutrient fluxes across river-estuary-coast continuum. Sci Total Environ 628-629: 1108-1120.

Chen, N., Wu, J., and Hong, H. (2012) Effect of storm events on riverine nitrogen dynamics in a subtropical watershed, southeastern China. Sci Total Environ 431: 357-365.

695 Taxonomy, Clinical Aspects, and Emerging Antimicrobial Resistance. Clin Microbiol Rev 32.

De Carlo, E.H., Hoover, D.J., Young, C.W., Hoover, R.S., and Mackenzie, F.T. (2007) Impact of storm runoff from tropical watersheds on coastal water quality and productivity. Appl Geochem 22: 1777-1797.

700 De Jesus Crespo, R., Wu, J., Myer, M., Yee, S., and Fulford, R. (2019) Flood protection ecosystem services in the coast of Puerto Rico: Associations between extreme weather, flood hazard mitigation and gastrointestinal illness. Sci Total Environ 676: 343-355.

Du, J., Park, K., Dellapenna, T.M., and Clay, J.M. (2019) Dramatic hydrodynamic and sedimentary responses in Galveston Bay and adjacent inner shelf to Hurricane Harvey. Sci 705 Total Environ 653: 554-564. 
Engene, N., Tronholm, A., and Paul, V.J. (2018) Uncovering cryptic diversity of Lyngbya: the new tropical marine cyanobacterial genus Dapis (Oscillatoriales). J Phycol 54: 435-446.

Fabricius, K.E. (2005) Effects of terrestrial runoff on the ecology of corals and coral reefs: review and synthesis. Mar Pollut Bull 50: 125-146.

710 Frias-Lopez, J., Zerkle, A.L., Bonheyo, G.T., and Fouke, B.W. (2002) Partitioning of bacterial communities between seawater and healthy, black band diseased, and dead coral surfaces. Appl Environ Microbiol 68: 2214-2228.

Fuhrman, J.A., Cram, J.A., and Needham, D.M. (2015) Marine microbial community dynamics and their ecological interpretation. Nat Rev Microbiol 13: 133-146.

715 Gao, Y., Zhu, B., Yu, G., Chen, W., He, N., Wang, T., and Miao, C. (2014) Coupled effects of biogeochemical and hydrological processes on $\mathrm{C}, \mathrm{N}$, and $\mathrm{P}$ export during extreme rainfall events in a purple soil watershed in southwestern China. J Hydrol 511: 692-702.

Glasl, B., Webster, N.S., and Bourne, D.G. (2017) Microbial indicators as a diagnostic tool for assessing water quality and climate stress in coral reef ecosystems. Mar Biol 164: 91.

720 Gloor, G.B., Macklaim, J.M., Pawlowsky-Glahn, V., and Egozcue, J.J. (2017) Microbiome Datasets Are Compositional: And This Is Not Optional. Front Microbio/ 8.:

Groisman, P.Y., Knight, R.W., Easterling, D.R., Karl, T.R., Hegerl, G.C., and Razuvaev, V.N. (2005) Trends in Intense Precipitation in the Climate Record. J Clim 18: 1326-1350.

Grossmann, M.M., Gallager, S.M., and Mitarai, S. (2015) Continuous monitoring of near-bottom mesoplankton communities in the East China Sea during a series of typhoons. J Oceanogr 71: 115-124.

Haapkylä, J., Unsworth, R.K.F., Flavell, M., Bourne, D.G., Schaffelke, B., and Willis, B.L. (2011) Seasonal Rainfall and Runoff Promote Coral Disease on an Inshore Reef. PLoS One 6: e16893.

730 Harii, S., Hongo, C., Ishihara, M., Ide, Y., and Kayanne, H. (2014) Impacts of multiple disturbances on coral communities at Ishigaki Island, Okinawa, Japan, during a 15 year survey. Mar Ecol Prog Ser 509: 171-180.

Hassard, F., Gwyther, C.L., Farkas, K., Andrews, A., Jones, V., Cox, B., et al. (2016) Abundance and Distribution of Enteric Bacteria and Viruses in Coastal and Estuarine

735 Sediments-A Review. Front Microbiol 7: 1692.

Hennessy, K.J., Gregory, J.M., and Mitchell, J.F.B. (1997) Changes in daily precipitation under enhanced greenhouse conditions. Clim Dyn 13: 667-680.

Herbeck, L.S., Unger, D., Krumme, U., Liu, S.M., and Jennerjahn, T.C. (2011) Typhoon-induced precipitation impact on nutrient and suspended matter dynamics of a tropical estuary

$740 \quad$ affected by human activities in Hainan, China. Estuar Coast Shelf Sci 93: 375-388.

Hongo, C. and Yamano, H. (2013) Species-Specific Responses of Corals to Bleaching Events on Anthropogenically Turbid Reefs on Okinawa Island, Japan, over a 15-year Period (1995-2009). PLoS One 8: e60952.

Inoue, M., Ishikawa, D., Miyaji, T., Yamazaki, A., Suzuki, A., Yamano, H., et al. (2014)

$745 \quad$ Evaluation of $\mathrm{Mn}$ and Fe in coral skeletons (Porites spp.) as proxies for sediment loading and reconstruction of 50 yrs of land use on Ishigaki Island, Japan. Coral Reefs 33: 363373.

Jamieson, R., Gordon, R., Joy, D., and Lee, H. (2004) Assessing microbial pollution of rural surface waters: A review of current watershed scale modeling approaches. Agric Water

$750 \quad$ Manage 70: 1-17.

King, A.L. and Barbeau, K.A. (2011) Dissolved iron and macronutrient distributions in the southern California Current System. J Geophys Res 116: 349.

Lewis, S.E., Schaffelke, B., Shaw, M., Bainbridge, Z.T., Rohde, K.W., Kennedy, K., et al. (2012) Assessing the additive risks of PSIl herbicide exposure to the Great Barrier Reef. Mar

$755 \quad$ Pollut Bull 65: 280-291.

Lin, Y.-T., Lin, Y.-F., Tsai, I.J., Chang, E.-H., Jien, S.-H., Lin, Y.-J., and Chiu, C.-Y. (2019) 
Structure and Diversity of Soil Bacterial Communities in Offshore Islands. Sci Rep 9: 4689. Loch, T.P. and Faisal, M. (2015) Emerging flavobacterial infections in fish: A review. J Advert Res 6: 283-300.

Love, M.I., Huber, W., and Anders, S. (2014) Moderated estimation of fold change and dispersion for RNA-seq data with DESeq2. Genome Biol 15: 550.

Masucci, G.D. and Reimer, J.D. (2019) Expanding walls and shrinking beaches: loss of natural coastline in Okinawa Island, Japan. PeerJ 7: e7520.

McMurdie, P.J. and Holmes, S. (2013) phyloseq: an R package for reproducible interactive analysis and graphics of microbiome census data. PLOS One 8: e61217.

Mei, W. and Xie, S.-P. (2016) Intensification of landfalling typhoons over the northwest Pacific since the late 1970s. Nat Geosci 9: 753.

Mistri, M., Pitacco, V., Granata, T., Moruzzi, L., and Munari, C. (2019) When the levee breaks: Effects of flood on offshore water contamination and benthic community in the

770 Mediterranean (Ionian Sea). Mar Pollut Bull 140: 588-596.

O'Connor, J.J., Lecchini, D., Beck, H.J., Cadiou, G., Lecellier, G., Booth, D.J., and Nakamura, Y. (2016) Sediment pollution impacts sensory ability and performance of settling coral-reef fish. Oecologia 180: 11-21.

Oksanen, J., Guillaume Blanchet, F., Friendly, M., Kindt, R., Legendre, P., McGlinn, D., et al. (2019) vegan: Community Ecology Package. R package version 2.5-4.

Omija, T. (2004) Terrestrial inflow of soils and nutrients. Coral Reefs of Japan 47: 64-68.

Omori, M. (2011) Degradation and restoration of coral reefs: Experience in Okinawa, Japan. Mar Biol Res 7: 3-12.

Paerl, H.W., Bales, J.D., Ausley, L.W., Buzzelli, C.P., Crowder, L.B., Eby, L.A., et al. (2001) Ecosystem impacts of three sequential hurricanes (Dennis, Floyd, and Irene) on the United States' largest lagoonal estuary, Pamlico Sound, NC. Proc Natl Acad Sci U S A 98: 56555660.

Paerl, H.W., Crosswell, J.R., Van Dam, B., Hall, N.S., Rossignol, K.L., Osburn, C.L., et al. (2018) Two decades of tropical cyclone impacts on North Carolina's estuarine carbon, nutrient and phytoplankton dynamics: implications for biogeochemical cycling and water quality in a stormier world. Biogeochemistry 141: 307-332.

Paerl, H.W., Valdes, L.M., Joyner, A.R., Peierls, B.L., Piehler, M.F., Riggs, S.R., et al. (2006) Ecological response to hurricane events in the Pamlico Sound system, North Carolina, and implications for assessment and management in a regime of increased frequency.

$790 \quad$ Estuaries Coasts 29: 1033-1045.

Pandey, P.K., Kass, P.H., Soupir, M.L., Biswas, S., and Singh, V.P. (2014) Contamination of water resources by pathogenic bacteria. $A M B$ Express 4: 51.

Patterson, K.L., Porter, J.W., Ritchie, K.B., Polson, S.W., Mueller, E., Peters, E.C., et al. (2002) The etiology of white pox, a lethal disease of the Caribbean elkhorn coral, Acropora

795 palmata. Proc Natl Acad Sci U S A 99: 8725-8730.

Pearman, J.K., Afandi, F., Hong, P., and Carvalho, S. (2018) Plankton community assessment in anthropogenic-impacted oligotrophic coastal regions. Environ Sci Pollut Res Int 25: 31017-31030.

Perrone, J. and Madramootoo, C.A. (1998) Improved curve number selection for runoff $800 \quad$ prediction. Can J Civ Eng 25: 728-734.

Peters, E.C. (2015) Diseases of Coral Reef Organisms. In Coral Reefs in the Anthropocene. Birkeland, C. (ed). Dordrecht: Springer Netherlands, pp. 147-178.

Philipp, E. and Fabricius, K. (2003) Photophysiological stress in scleractinian corals in response to short-term sedimentation. J Exp Mar Bio Ecol 287: 57-78.

805 Pollock, F.J., Lamb, J.B., Field, S.N., Heron, S.F., Schaffelke, B., Shedrawi, G., et al. (2014) Sediment and turbidity associated with offshore dredging increase coral disease prevalence on nearby reefs. PLoS One 9: e102498. 
Pruzzo, C., Huq, A., Colwell, R.R., and Donelli, G. (2005) Pathogenic Vibrio Species in the Marine and Estuarine Environment. In Oceans and Health: Pathogens in the Marine Environment. Belkin, S. and Colwell, R.R. (eds). Boston, MA: Springer US, pp. 217-252.

Quast, C., Pruesse, E., Yilmaz, P., Gerken, J., Schweer, T., Yarza, P., et al. (2013) The SILVA ribosomal RNA gene database project: improved data processing and web-based tools. Nucleic Acids Res 41: D590-6.

R Core Team (2018). R: A language and environment for statistical computing. R Foundation for Statistical Computing, Vienna, Austria. URL https://www.R-project.org/.

Riegl, B. and Branch, G.M. (1995) Effects of sediment on the energy budgets of four scleractinian (Bourne 1900) and five alcyonacean (Lamouroux 1816) corals. J Exp Mar Bio Ecol 186: 259-275.

Sañudo-Wilhelmy, S.A., Kustka, A.B., Gobler, C.J., Hutchins, D.A., Yang, M., Lwiza, K., et al. 820 (2001) Phosphorus limitation of nitrogen fixation by Trichodesmium in the central Atlantic Ocean. Nature 411: 66-69.

Sharma, S., Sachdeva, P., and Virdi, J.S. (2003) Emerging water-borne pathogens. Appl Microbiol Biotechnol 61: 424-428.

Sheridan, C., Baele, J.M., Kushmaro, A., Fréjaville, Y., and Eeckhaut, I. (2014) Terrestrial runoff influences white syndrome prevalence in SW Madagascar. Mar Environ Res 101: 44-51.

Shinn, E.A., Smith, G.W., Prospero, J.M., Betzer, P., Hayes, M.L., Garrison, V., and Barber, R.T. (2000) African dust and the demise of Caribbean Coral Reefs. Geophys Res Lett 27: 3029-3032.

Siegesmund, M.A., Johansen, J.R., Karsten, U., and Friedl, T. (2008) Coleofasciculus gen. Nov. (Cyanobacteria): Morphological and molecular criteria for revision of the genus Microcoleus gomont(1). J Phycol 44: 1572-1585.

Silva, J., Leite, D., Fernandes, M., Mena, C., Gibbs, P.A., and Teixeira, P. (2011) Campylobacter spp. as a Foodborne Pathogen: A Review. Front Microbiol 2: 200.

Solo-Gabriele, H.M., Wolfert, M.A., Desmarais, T.R., and Palmer, C.J. (2000) Sources of Escherichia coli in a coastal subtropical environment. Appl Environ Microbio/ 66: 230-237.

Soo, R.M., Skennerton, C.T., Sekiguchi, Y., Imelfort, M., Paech, S.J., Dennis, P.G., et al. (2014) An expanded genomic representation of the phylum cyanobacteria. Genome Biol Evol 6: 1031-1045.

Sussman, M., Willis, B.L., Victor, S., and Bourne, D.G. (2008) Coral Pathogens Identified for White Syndrome (WS) Epizootics in the Indo-Pacific. PLoS One 3: e2393.

Sutherland, K.P., Porter, J.W., and Torres, C. (2004) Disease and immunity in Caribbean and Indo-Pacific zooxanthellate corals. Mar Ecol Prog Ser 266: 273-302.

Sutherland, K.P., Shaban, S., Joyner, J.L., Porter, J.W., and Lipp, E.K. (2011) Human pathogen shown to cause disease in the threatened eklhorn coral Acropora palmata. PLoS One 6:

845 e23468.

Vizcaino, M.I., Johnson, W.R., Kimes, N.E., Williams, K., Torralba, M., Nelson, K.E., et al. (2010) Antimicrobial resistance of the coral pathogen Vibrio coralliilyticus and Caribbean sister phylotypes isolated from a diseased octocoral. Microb Ecol 59: 646-657.

850 patterns and potential drivers. Dis Aquat Organ 69: 33-40.

Wang, B., Yang, Y., Ding, Q.-H., Murakami, H., and Huang, F. (2010) Climate control of the global tropical storm days (1965-2008): Climate Control Of Tropical Storm Days. Geophys Res Lett 37.

Weber, M., de Beer, D., Lott, C., Polerecky, L., Kohls, K., Abed, R.M.M., et al. (2012)

855 Mechanisms of damage to corals exposed to sedimentation. Proc Natl Acad Sci U S A 109: E1558-67.

Weiskel, P.K., Howes, B.L., and Heufelder, G.R. (1996) Coliform Contamination of a Coastal Embayment: Sources and Transport Pathways. Environ Sci Technol 30: 1872-1881. 
Wetz, M.S. and Paerl, H.W. (2008) Estuarine Phytoplankton Responses to Hurricanes and Tropical Storms with Different Characteristics (Trajectory, Rainfall, Winds). Estuaries Coasts 31: 419-429.

Willis, A. and Bunge, J. (2015) Estimating diversity via frequency ratios. Biometrics 71: 10421049.

Willis, A., Bunge, J., and Whitman, T. (2017) Improved detection of changes in species richness in high diversity microbial communities. J R Stat Soc C 66: 963-977.

Wilson, B., Aeby, G.S., Work, T.M., and Bourne, D.G. (2012) Bacterial communities associated with healthy and Acropora white syndrome-affected corals from American Samoa. FEMS Microbiol Ecol 80: 509-520.

Witt, V., Wild, C., and Uthicke, S. (2012) Terrestrial runoff controls the bacterial community composition of biofilms along a water quality gradient in the Great Barrier Reef. Appl Environ Microbiol 78: 7786-7791.

Wooldridge, S.A. (2009) Water quality and coral bleaching thresholds: formalising the linkage for the inshore reefs of the Great Barrier Reef, Australia. Mar Pollut Bull 58: 745-751.

875 dilution inductively coupled plasma mass spectrometry after $\mathrm{Mg}(\mathrm{OH})_{2}$ coprecipitation. Anal Chim Acta 367: 183-191.

Wu, J., Chung, S.-W., Wen, L.-S., Liu, K.-K., Chen, Y.-L.L., Chen, H.-Y., and Karl, D.M. (2003) Dissolved inorganic phosphorus, dissolved iron, and Trichodesmium in the oligotrophic South China Sea: Phosphate, Iron, And Nitrogen Fixation In The South China Sea. Global

880 Biogeochem Cycles 17: 8-1-8-10.

Yamano, H. and Watanabe, T. (2016) Coupling Remote Sensing and Coral Annual Band Data to Investigate the History of Catchment Land Use and Coral Reef Status. In Coral Reef Science: Strategy for Ecosystem Symbiosis and Coexistence with Humans under Multiple Stresses. Kayanne, H. (ed). Tokyo: Springer Japan, pp. 47-53.

885 Yamazaki, A., Watanabe, T., Tsunogai, U., Hasegawa, H., and Yamano, H. (2015) The coral $\delta_{15} \mathrm{~N}$ record of terrestrial nitrate loading varies with river catchment land use. Coral Reefs.

Zhang, J.-Z., Kelble, C.R., Fischer, C.J., and Moore, L. (2009) Hurricane Katrina induced nutrient runoff from an agricultural area to coastal waters in Biscayne Bay, Florida. Estuar Coast Shelf Sci 84: 209-218.

890 Zhou, W., Yin, K., Harrison, P.J., and Lee, J.H.W. (2012) The influence of late summer typhoons and high river discharge on water quality in Hong Kong waters. Estuar Coast Shelf Sci 111: 35-47.

Zimmer, B.L., May, A.L., Bhedi, C.D., Dearth, S.P., Prevatte, C.W., Pratte, Z., et al. (2014) Quorum sensing signal production and microbial interactions in a polymicrobial disease of corals and the coral surface mucopolysaccharide layer. PLoS One 9: e108541. 